\title{
NUMERICAL SIMULATION OF MULTIBEAM SYSTEMS BY EL\&ION CODE
}

\section{P.A. Martynenko \\ National Science Center “Kharkov Institute of Physics and Technology”, Kharkiv, Ukraine E-mail: martynenkopetr91@gmail.com}

Based on the tube method, taking into account the three second law for the current in each tube, the program EL\&ION for preliminary rapid numerical analysis of the electron-optical system was developed, using which the system was developed for generating an ion beam of reactive gases with an energy of up to $50 \mathrm{keV}$ and a current of $10 . .20 \mathrm{~mA}$ in the presence of high-density electron beam.

PACS: $29.25 . \mathrm{Ni}$

\section{INTRODUCTION}

Beams of accelerated electrons and ions are widely used in modern nuclear physics technologies. The development of new systems for charged particles accelerating, based on ideas proposed more than half a century ago, continues to be relevant for the creation of new electron and ion accelerators [1 - 3]. This work is devoted to the study of the possibility of numerically calculating the formation system with a joint ion and highperveance electron beam (HPEB) used in the model of a collective accelerator. The formation systems used for the injector part of the accelerator consist of many electrodes with complex configuration. Their choice is a difficult task in optimizing the beam parameters $[4,5]$.

\section{MULTIBEAM SYSTEM SIMULATION}

The numerical calculation of the collective accelerator injectors leads to the formation system creation of the required parameter charged particle beams. The difficulty is the calculation of the self-consistent state [6] of the joint flows of electrons and various types of ions obtained from ion sources, both plasma type and solidstate type [7].

The charged particle flows are modeled in an axisymmetric electrode system. The influence of the intrinsic magnetic field of the beams, ionization and secondary emission processes is neglected in the calculations. So as the computational time is reduced and it is possible to compare the calculation results with experimental data both for a high-current electron injector and for a thermal emitter of alkali metal ions. The ion and electron beam dynamics are calculated using the EL\&ION code, which implements the current tube method for solving stationary self-consistent problems [8]. Using this method allows to solve such problems more economically in time, in contrast to the use of the particle in cells method [9].

A rectangular uniform grid was used in the simulation, with the number of cells $300 \times 100$. The required number of current tubes and the dimensions of the spatial grid were selected from the condition of ensuring a given accuracy in calculating the perveance of flows. Thus the use of $\sim 100$ current tubes and $0.2 \mathrm{~cm}$ grid spacing allows one to achieve the calculation accuracy necessary for creating experimental samples of the highperveance charged particle guns.

An ion beam with energies up to $50 \mathrm{keV}$ is injected through an opening in the cathode of the electron gun. The current of nitrogen ions can reach $30 \mathrm{~mA}$ [10]. Fig. 1 shows that the ions completely pass through the cathode into the space behind the anode of the electron gun, which is at zero potential and is connected to the drift tube.

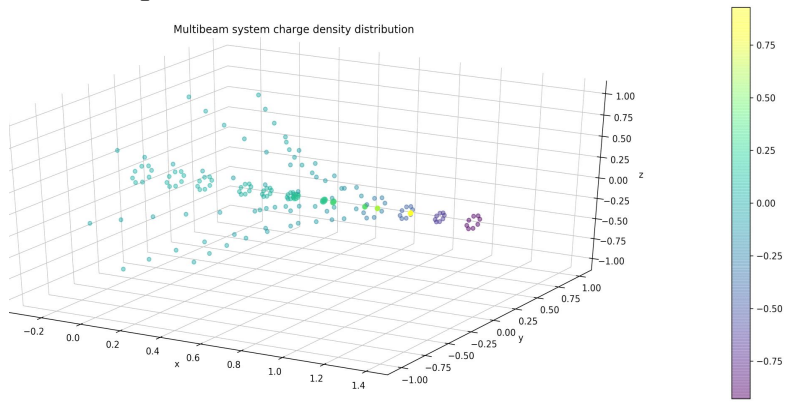

Fig. 1. The charge density distribution and trajectories of charged particles

\section{RESULTS}

The formation system calculation results of a convergent tubular beam were used in the designing and manufacturing of the electron gun for technological purposes.

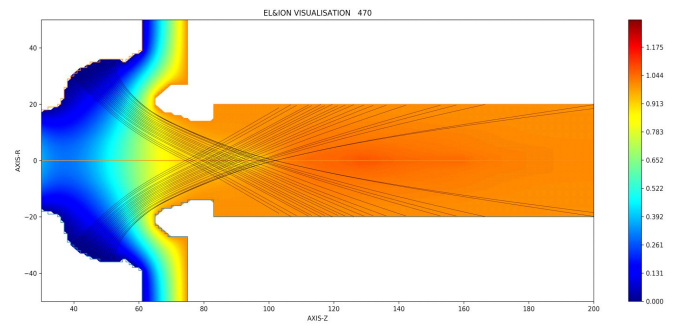

Fig. 2. The HPEB potential distribution and trajectories of charged particles

The test results of the cathode assembly gun at a power pulse amplitude of up to $100 \mathrm{kV}$ showed no breakdowns. The recorded amplitude current to the collector isolated from the anode of the gun coincided with the calculated value with good accuracy. The collector current was recorded by an oscilloscope by the voltage drop across the resistance of the collector grounding. According to the results of the calculation of the formation system see Fig. 2, the location of the near cathode equipotential for the design of the electron gun with a control grid was determined. The experimental results showed the possibility of $100 \%$ modulation of the beam current at a frequency of less than $10 \mathrm{MHz}$ without the use of an external RF generator [11]. As can be seen from Fig. 3, the presence of an ionic space charge in the HPEB crossover compensates the Coulomb forces of repulsion of electrons. Under conditions of ionic compensation, the intrinsic magnetic field of a high-current 
electron beam can significantly affect the motion of electrons and ions in the space behind anode, which leads to compression of the electron beam.

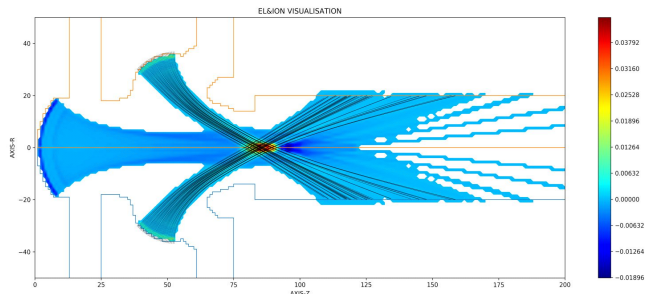

Fig. 3. The charge density distribution and trajectories of $H P E B$

\section{CONCLUSIONS}

Experimental studies must be supplemented by numerical calculations of the electron-optical system in the presence of plasma near the axis, taking into account the action of the magnetic field generated by the highcurrent beam.

The first version of the EL\&ION program was written in the early 80's and was operated on a BESM-6 computer. In the early $90 \mathrm{~s}$, the program was adapted for personal computers with operating systems such as MSDOS and WINDOWS. The program is connected to the well-known library of graphic output programs Grafor [12], adapted for computers using these systems. The computational time is heavily dependent on the processor performance. The move to the $7^{\text {th }}$ Generation Intel ${ }^{\circledR}$ Core TM 17 Processors reduces this time by more than 5 times compared with the system of the same architecture, based on the Intel $\AA$ Pentium ${ }^{\circledR}$ Processors. To visualize the results, a script was written in Python 3 that implements the processing of data files using the matplotlib 3.0.3 library. Graphing is performed in the remote access operating mode on the server https://colab.research.google.com.

\section{REFERENCES}

1. G.G. Aseev, A.G. Korostelev, G.G. Kuznetsova, A.G. Lymar', P.A. Martynenko, N.A. Khizhnyak. To the calculation of an accelerating structure of an ion collective accelerator // Proceedings of the $I X$ All-Union Meeting on charged particle acceleration, Dubna, September, 1985, v. II, p. 203-206.

2. N.A. Khizhnyak, A.G. Lymar. Status of the Kharkov's Linear Collective Accelerator // Proceed- ings of the Second International Conference on ADTT and Applications, Kalmar, Sweden, June 3-7, 1996, v. 2, p. 1087-1089.

3. V.A. Balakirev, A.M. Gorban, I.I. Magda, V.E. Novikov, I.N. Onishchenko, S.S. Pushkarev. Collective ion acceleration by a modulated high-current REB // Plasma Physics Reports. 1997, v. 23(4), p. 323-327.

4. P.A. Martynenko. Simulating multigun system with Langmuir law emission current // Problems of Atomic Science and Technology. Series "Plasma Electronics and New Methods of Acceleration". 2018, № 4, p. 27-29.

5. P.A. Martynenko. Multibeam system simulation // Problems of Atomic Science and Technology. Series "Plasma Physics”. 2019, № 1, p. 168-171.

6. A.G. Lymar, P.A. Martynenko, N.A. Khizhnyak. Slozhnoe povedenie v modeli elektronnoy pushki s termokatodom // Problems of Atomic Science and Technology. Series "Plasma Electronics and New Methods of Acceleration”. 1998, № 1, p. 79.

7. P.A. Martynenko. The forming system simulation for reactive gas ion source with decreased neutral gas inleakage // Problems of Atomic Science and Technology. Series “Plasma Physics”. 2017, № 1, p. 152-154.

8. P.T. Kirstein, G.S. Kino, W.E. Waters. SpaceCharge Flow. Publication, New York, NY: "McGraw-Hill", 1967, 537 p.

9. Hockney R., Eastwood J. Computer Simulation Using Particles. Francis: IOP Publ. Ltd. 1988, 540 p.

10. A. Guglya, V. Drakin, A. Lymar, N. Stervoedov. High-current and broad-beam ion implanter // Vacuum. 2003, v. 70, Issue 2, p. 353-358.

11. A.A. Bakumenko, V.V. Belikov, A.V. Zvyagintsev, V.I. Lyul'chenko, A.G. Lymar', P.A. Martynenko, A.V. Suryadnyj. Control-grid electron gun as a source of modulated electron beam for a collective accelerator // Voprosy atomnoj nauki i tekhniki. 1989, № 6(6), p. 84-85 (in Russian).

12. S.B. Bazarov, Yu.M. Bayakovsky, F.F. Seidalieva, A.Yu. Skachkov. Adaptation of software library GRAFOR for Windows and Linux: Preprint № 27, Inst. Appl. Math. the Russian Academy of Science. M. 2002 (in Russian).

Article received 29.01.2020

\section{ЧИСЛЕННОЕ МОДЕЛИРОВАНИЕ МНОГОПУЧКОВЫХ СИСТЕМ С ПОМОЩЬЮ ЕL\&ION-КОДА}

\section{П.А. Мартыненко}

На основе метода трубок с учетом закона трех вторых для тока в каждой трубке разработана программа EL-ION предварительного быстрого численного анализа электронно-оптической системы, с помощью которой была рассчитана система формирования пучка ионов реакционно-способных газов с энергией до 50 кэВ и током $10 \ldots 20$ мА при наличии высокоплотного электронного пучка.

\section{ЧИСЕЛЬНЕ МОДЕЛЮВАННЯ БАГАТОПУЧКОВИХ СИСТЕМ ЗА ДОПОМОГОЮ ЕL\&ION-КОДУ}

\section{П.О. Мартиненко}

На основі методу трубок з урахуванням закону трьох других для струму в кожній трубці розроблена програма EL-ION попереднього швидкого чисельного аналізу електронно-оптичної системи, за допомогою якої була розрахована система формування пучка іонів реакційно-здатних газів 3 енергією до 50 кеВ і струмом $10 . .20$ мА при наявності електронного пучка з високою густиною. 